Disponível em www.scielo.br/paideia

\title{
A persuasão e o dinamismo psíquico em sermões de Antônio Vieira
}

\author{
Sandro Rodrigues Gontijo \\ Marina Massimi \\ Universidade de São Paulo, Ribeirão Preto-SP, Brasil
}

Resumo: Dentro de uma história dos saberes psicológicos desenvolvida no Brasil, identificamse várias origens e influências, dentre elas uma rica herança colonial. No século XVII, o tema da persuasão é produtivamente explorado pela oratória religiosa da época, mais especificamente a dos jesuítas - ordem religiosa de influência marcante no Brasil - a qual pertence o Pe. Antônio Vieira. Essa oratória proporciona um modelo explicativo do "psiquismo" humano, além de propor um mecanismo de intervenção neste, através da palavra, pelo uso da retórica aristotélica. Buscase averiguar de que maneira Vieira articula em seus sermões os recursos retóricos para intervir no universo "psíquico" dos ouvintes e conseguir a persuasão, bem como evidenciar a psicologia filosófica dos jesuítas que o fundamenta. Pode-se também, compreender um pouco mais sobre a visão de homem estabelecida no período.

Palavras-chave: Persuasão. Retórica. Vieira. Dinamismo psíquico.

\section{Persuasion and psychic dynamism in the sermons by Antônio Vieira}

\begin{abstract}
Various origins and influences may be identified within the history of psychological knowledge developed in Brazil, among them a rich colonial inheritance. The theme persuasion was productively explored in the $17^{\text {th }}$ century by the religious oratory of the time, more specifically that of the Jesuits - a religious order of remarkable influence in Brazil - to which Father Antonio Vieira belonged to. This oratory provides an explanatory model for human "psychism", besides proposing that it should be intervened by a mechanism using Aristotle's rhetoric through words. It is sought to verify in which way Vieira articulates rhetoric resources in his sermons in order to intervene in the "psychic" universe of the listeners and obtain persuasion, as well as to evidence the presence of the Jesuit philosophical psychology in these sermons. One may also understand some more about the vision of man as established in that period
\end{abstract}

Keywords: Persuasion. Rhetoric. Vieira. Psychic dynamism.

\section{La persuasión y el dinamismo psíquico en sermones de Antônio Vieira}

Resumen: Podemos identificar dentro de una historia de los saberes psicológicos desenvuelta en Brasil, varios orígenes e influencias, entre ellos una rica herencia colonial. En el siglo XVII, el tema de la persuasión es productivamente explorado por la oratoria religiosa de la época, mas específicamente la de los jesuitas - orden religiosa de grande influencia en Brasil - a la cual pertenece el Padre Antônio Vieira. Esa oratoria proporciona un modelo explicativo del "psiquismo" humano, además de proponer un mecanismo de intervención en éste, a través de la palabra, por el uso de la retórica aristotélica. Buscase averiguar de qué manera Vieira articula en sus sermones los recursos retóricos para intervenir en el universo "psíquico" de los oyentes y conseguir la persuasión, bien como evidenciar la psicología filosófica de los jesuitas que lo fundamenta. Pódese también, comprender un poco mas sobre la visión del hombre establecida en el período.

Palabras clave: Persuasión. Retórica. Vieira. Dinamismo psíquico. 


\section{Introdução}

É possível tentar identificar a presença, no Brasil, de "conhecimentos psicológicos" - ou idéias psicológicas $^{1}$ - que precedem a psicologia atualmente estruturada enquanto ciência. A presente pesquisa realizou-se a partir de um recorte temporal, atendo-se ao Brasil colonial do século XVII e sua oratória religiosa. A cultura do período, rotulado como barroco, é uma cultura de persuasão, sendo a pregação religiosa o meio de comunicação de massa privilegiado; o proliferar dos tratados sobre esta prática documenta sua relevância cultural e social, sendo que o estudo destas questões pertence à historia intelectual e literária, bem como à social e religiosa (Maraval, 1997).

Para tanto, investigou-se no território da pregação, os conceitos referentes ao dinamismo psíquico, através das peças de oratória sagrada escritas pelo Pe. Antônio Vieira, que foram preservadas (Vieira, 1993). É importante ressaltar que a pregação representa uma atividade marcada pela oralidade, portanto não há necessariamente um registro de escrita que a acompanhe. No caso de Antônio Vieira, segundo ele próprio, a publicação de sua obra sermonária deveu-se a uma obediência ao prepósito-geral da Companhia, Pe. João Paulo Oliva, que assim o pediu, bem como à necessidade de estabelecer a autoria devida - conforme assinalado pelo próprio Vieira - à "corrupção com que andam estampados debaixo do meu nome, e traduzidos em diferentes línguas muitos sermões, ou supostos

\footnotetext{
${ }^{1}$ Entende-se aqui o campo da história das idéias psicológicas o proposto por Massimi, que seria o campo que "se ocupa daqueles aspectos específicos da 'visão de mundo’ de uma determinada cultura, relacionada a conceitos e práticas que na atualidade podem ser genericamente entendidos como psicológicos. A definição do que é psicológico, nesse caso, deve permanecer necessariamente indeterminada e vaga, quase como denominação convencional e provisória a ser substituída no decorrer da pesquisa pela terminologia e demarcação de campo próprias aos específicos universos socioculturais estudados" (Massimi, 2000, p. 31). O termo "visão de mundo" utilizado por Massimi é o definido por Goldmann, citado por Chartier, segundo o qual "visão de mundo seria um conjunto de aspirações, de sentimentos e de idéias que reune os membros de um mesmo grupo (de uma classe social, na maioria das vezes) e os opõe aos outros grupo" (Massimi, 2000, p. 31)
}

totalmente, não sendo meus; ou sendo meus na substância, tomados só de memória, e por isso informes; ou, finalmente impressos por cópias defeituosas e depravadas, com que em todos ou quase todos, vieram a ser maiores os erros dos que eu conheci sempre nos próprios originais" (Vieira, 1993, p. 61-62). Ainda no caso de Vieira, alguns sermões publicados nunca chegaram a ser pregados, assim como alguns só vieram a ser transcritos após a respectiva pregação.

$\mathrm{O}$ dinamismo psíquico diz respeito a todo processo de persuasão e dissuasão, baseado nos métodos da retórica aristotélica, estabelecida pelo orador para com seus ouvintes, para tentar obter o convencimento destes. Segundo Reale e Antiseri (1990), a retórica para Aristóteles:

\begin{abstract}
...é uma espécie de 'metodologia do persuadir', uma arte que analisa e define os procedimentos através dos quais o homem procura convencer os outros homens e identifica as suas estruturas fundamentais. Assim, sob o aspecto formal, a retórica apresenta analogias com a lógica, que estuda as estruturas do pensar e do raciocinar. (...) Analogamente, a retórica estuda os procedimentos com os quais os homens aconselham, acusam, defendem-se e elogiam (com efeito, essas são todas atividades específicas do persuadir) em geral, não movendo-se a partir de conhecimentos científicos, mas de opiniões prováveis. (Reale \& Antiseri, 1990).
\end{abstract}

Inclui-se, no processo, a utilização de elementos e técnicas visando mobilizar no ouvinte emoções que auxiliem o orador a conseguir a adesão daquele às doutrinas propostas e a conseqüente modificação da conduta. Estas considerações, portanto, fundamentam o interesse em investigar seja o conteúdo em matéria "psicológica" proposto pelos pregadores, como também a utilização feita por eles de técnicas retóricas.

\section{A persuasão em Vieira}

Escolheu-se aqui nas Obras Completas do Padre Antônio Vieira, Sermões (Vieira, 1993), principalmente os sermões quaresmais, em que onde ao se privilegiar o tema da conversão (sendo a Quares- 
ma (Pécora, 2003)² um tempo litúrgico propício), evidencia-se mais claramente o mecanismo persuasivo em sua ação para, através da retórica, disciplinar o corpo, ordenar os afetos, a fim de que estes pudessem agir sobre a vontade e alterar a conduta, como pressupõe a cultura da época. A palavra, tomando corpo na elocução, penetra os ânimos e atinge o plano moral, tornando-se assim ética: assim sendo, a palavra eloqüente não apenas veicula a coisa, mas sugere também comportamento diante dela.

Ao selecionar parte da obra de Vieira, atendese a um recorte de pesquisa que não deixa de trazer em si uma certa arbitrariedade, no sentido de que, como diria o próprio Vieira a respeito de sua obra de Sermões:

Os que de presente tens nas mãos (e mais ainda os seguintes) serão todos diversos, e não continuados, quaresmais, santorais, e mariais inteiros, como se usa. Mas o meu intento não é fazer sermonário, e estampar os sermões que fiz. Assim como foram pregados ao acaso, e sem ordem assim tos ofereço. Porque hás-de saber que, havendo trinta e sete anos, que as voltas do mundo me arrebataram da minha província do Brasil, e me trazem pelas da Europa, nunca pude professar o exercício de pregador, e muito mais de pregador ordinário, por não ter lugar certo, nem tempo; já aplicado a outras ocupações de Deus e da Pátria, já impedido de minhas freqüentes enfermidades, por ocasião das quais deixei de recitar alguns sermões, não poucos, que já tinha prevenido, e também, agora, se darão à estampa (Vieira, 1993, p. 62-63).

Por outro lado, mesmo "pregados ao acaso" e "sem ordem", tais sermões não deixam de seguir certa "globalidade relativa" e dar uma finalidade clara

\footnotetext{
2 "O ano eclesiástico, como é sabido, diz respeito à série de tempo e dias santos, definidos pela Igreja, que começa com a Primeira Domingo do Advento e fecha na última semana depois de Pentecostes. A celebração periódica dessas solenidades refere a memória, guarda e ensino dos mistérios e dogmas da Igreja, entidos ortodoxamente como legados de Cristo. Assim, um pregador, quando diz o seu sermão, deve ajusta-lo necessariamente aos significados doutrinários da ocasião. (...) ... Quaresma... nomeia o período de 46 dias que vai que vai da $4^{\text {a }}$ feira de Cinza (assim mesmo, no singular, como se diz no século XVII), e vai até o $1^{\circ}$ Domingo da Páscoa" (Pécora, 2003, p. 85).
}

à retórica, onde a dimensão "sacramental (...) fundamenta as analogias da retórica", como afirma Pécora (1994):

...é impraticável uma análise rigorosa da retórica desses sermões se não se examinar o valor que essa eficácia do divino recebe no seio da sua produção humana. Ou se, essa analise teria que se processar - como diz José Mattoso a propósito da "escrita da Historia" que considera adequada com "saber" - tendo em vista uma "lógica de base" que perpassa os sermões individuais e os "insere numa totalidade" com a qual mantêm uma relação essencial". E, como quer que se entenda essa relação essencial a ordenar os sermões, não é possível deixar de considerar o que, nela, se reporta à concepção cristã particular que justifica sua origem e proporciona sua finalidade (Pécora, 1994, p. 42).

Outro fato importante a ser considerado é que este trabalho ateve-se à parte da retórica que se liga mais diretamente à estrutura formal presente nos sermões e às análises que podem decorrer desta. Não tocando diretamente a parte que diz respeito a uma importante dimensão da eloqüência propriamente dita, que - como afirma Granada $(1945)^{3}$ - é a pronúncia: "à pronúncia cabe acomodar a voz, o gesto, e o rosto à coisa dita" (Granada, 1945, p. 490). Voz e gesto são elementos que estabelecem uma comunicação direta via sensorial, e em sua teatralidade expressam e articulam sentidos do universo interior, dando toda uma roupagem de intenção à palavra. É importante lembrar que os sermões são, a priori, organizados para serem pregados, sendo assim a forma tão importante quanto o conteúdo. É o modo como é dito, que dá força e substância à palavra. Para isso atenta o próprio Vieira (1993, p. 61): "Da folha que fica atrás (se a leste) haverás entendido a primeira razão, ou obrigação, porque começo a tirar da sepultura estes meus borrões, que sem a voz que os animava, ainda ressuscitados são cadáveres".

\footnotetext{
${ }^{3} \mathrm{O}$ teólogo e pregador espanhol, Luís de Granada, foi mestre da arte da palavra a serviço da evangelização, constituindo-se em modelo exemplar para várias gerações de pregadores católicos, em seus tratados, elaborara articulações explicitas entre os domínios da retórica sagrada e do conhecimento de si mesmo.
} 
Mesmo tendo sido Vieira a figura de eloqüência que foi, e possuindo seu modo próprio e ímpar de articular as palavras com seu modo de compreender a realidade, ainda assim, ele compartilha da visão de mundo de sua época e vive plenamente sua historicidade - o que é coerente com sua "visão sacramental" (Pécora, 1994, p. 41) da realidade. Como novamente afirma Pécora (1994, p. 44):

Afinal, não é obvio que Viera fosse o mesmo, ou, pelo menos, que tivesse escrito como os mesmos sentidos os exatos mesmos textos que escreveu, se não tivesse sido igualmente o Padre, católico, jesuíta, missionário e português que acabou sendo pelos tantos anos de seu quase século de vida.

A concepção de dinamismo psíquico própria dos Jesuítas - ordem religiosa de influência marcante no Brasil - ao qual pertence Vieira, é uma das mais bem constituídas: por se basear em uma concepção da estrutura antropológica advinda da tradição aristotélico-tomista, proporciona um modelo explicativo do "psiquismo" humano, além de propor um mecanismo de intervenção através da palavra, pelo uso da retórica aristotélica.

Segundo esta descrição, a análise da vida interior se daria a partir de certa visão de mundo e de homem. Esta análise assume a forma explicativa de uma espécie de topografia da alma, conforme proposta pelo historiador Bergamo (1991). Esta topografia oferece a possibilidade não apenas de articulação de conceitos que formam idéias psicológicas, mas também de ter acesso à teoria do conhecimento aristotélico-tomista que a fundamenta, e ainda é presente no século XVII.

Primeiramente, cabe uma pergunta: que alma é esta que está sendo "topografada"?

O mais antigo conceito de alma é o da psyché dos gregos. Aristóteles a traz como uma parte da visão de mundo grega - na qual todo o universo é composto de forma substancial e forma acidental. Nesse sentido Reale e Antiseri (1990) em sua leitura de Aristóteles afirmam que:

...Aristóteles remete-se à sua concepção metafísica hilemórfica da realidade, segundo a qual todas as coisas em geral são sínolos de matéria e forma, onde a matéria é potência e a forma é enteléquia ou ato. (...) Os corpos vivos tem vida mas não são vida. Assim, são substrato material e potencial do qual a alma é a 'forma' e 'ato'. '(...) Portanto, a alma é inteléquia primeira de um corpo físico que tem a vida em potência' (Reale \& Antiseri, 1990, p. 198).

Este conceito é apropriado (Assis, 2004) ${ }^{4}$ pelos autores cristãos e fundamentalmente reformulado, pois são introduzidos novos elementos da cultura cristã - como o tópico do Deus único e criador, do Livre-arbítrio, da Graça, da fé, da revelação e tantos outros - que não cabem na forma com que os gregos pensaram o seu mundo:

Em suma, desde Sócrates, os gregos passaram a ver na alma a verdadeira essência do homem, não sabendo pensar o homem senão em termos de corpo e alma - e toda a tradição platônica, pitagórica e o próprio Aristóteles (e, portanto, a maior parte da filosofia grega) consideram a alma imortal por natureza. Ora, a mensagem cristã propôs o problema do homem em termos completamente diferentes. Nos textos sacros, o termo 'alma' não aparece nas acepções gregas. $\mathrm{O}$ cristianismo não nega que, com a morte do homem, sobreviva algo dele; pelo contrário, fala expressamente dos mortos como sendo recebidos no 'seio de Abraão'. Entretanto, o cristianismo não aponta em absoluto para a imortalidade da alma, mas sim para a 'ressurreição dos mortos'. Essa é uma das marcas da nova fé. E a ressurreição implica no retorno também do corpo à vida (Reale e Antiseri, 1990, p. 392).

\footnotetext{
${ }^{4}$ Outro conceito importante para ajudar a compreender os demais é o de apropriação, colocado por Chartier e comentado por Assis em sua tese de doutoramento "...o autor introduziu a noção de apropriação, indicando que os grupos não apenas assimilam conceitos e idéias, mas possuem maneiras de se apropriar de um motivo intelectual ou de uma forma cultural transformando-os, fazendo usos diversos, realizando um trabalho sobre esse material". Ainda nos comentários feitos por Assis encontra-se uma propícia análise de Michel De Certeau que trabalhou o conceito de apropriação e considera o ato enunciativo possuindo quatro características que podem ser encontradas em diversas práticas: "opera no campo de um sistema lingüístico; instaura um presente relativo a um momento e a um lugar; e estabelece um contrato com o outro (o interlocutor) numa rede de lugares e de relações" (conforme citado por Assis, 2004, p. 12).
} 
É Tomás de Aquino (conforme citado por Reale \& Antiseri, 1990) $)^{5}$ quem faz a apropriação de Aristóteles. Ao invés de duas "dimensões", corpo e alma, o homem gozaria de três ${ }^{6}$ : "“corpo', 'alma', 'espírito', onde o 'espírito' é exatamente essa participação no divino através da fé, a abertura do homem para a Palavra divina e para a Sabedoria divina, que o preenche com uma nova força e, em certo sentido, lhe dá uma nova estatura ontológica" (Reale \& Antiseri, 1990, p. 387). Então a alma adquire um novo status; sendo o espírito a possibilidade do homem transcender ao mundano e ao sensível, e o corpo representar o "estar no mundo" do homem e ser fonte de conhecimento (o homem pode conhecer através do sensível), a alma tem quase que uma função integradora do homem; é ela que estabelece os vínculos entre as dimensões do homem. É a alma o lugar onde a pessoa apreende o mundo e o transcende. Sendo assim, como diz a máxima, "Tomás batiza Aristóteles", ou seja, traz para a acepção cristã a visão aristotélica. Pode-se então

\footnotetext{
${ }^{5}$ Através da cultura árabe, que em determinado momento da história tem grande influência na Europa, a obra de Aristóteles é redescoberta e atualizada para o contexto cristão. Os pressupostos filosóficos aristotélicos vão ao encontro de muitas das bases do cristianismo, encontrando em grandes nomes como Alberto Magno respaldo e propagação. Mas é em um dos discípulos de Alberto que os conceitos aristotélicos melhor se assentaram para produzir a base de um modelo filosóficoteológico, o qual até hoje nos chega fortemente o eco. Esse é Tomás de Aquino, nascido em Roccasecca, no sul do Lácio, em 1221, filho de um poderoso feudatário, Landolfo, conde de Aquino. Junta-se a ordem dos Dominicanos, a qual por ser de fundação recente e voltada à pregação nas classes populares, não gozava de grande prestígio. "Expoente entre os escolásticos, verdadeiro gênio metafísico e um dos maiores pensadores de todos os tempos, Tomás de Aquino elaborou um sistema de saber admirável pela transparência lógica e pela conexão orgânica entre as partes, de índole mais aristotélica do que platônico-agostiniana" (Reale \& Antiseri, 1990, p. 552). Alberto diz certa vez a respeito de seu discípulo: "Este moço que nós chamamos de 'boi mudo', mugirá tão forte que se fará ouvir no mundo inteiro!”.

${ }^{6}$ Estas três dimensões são do âmbito de como se dá o conhecimento, e não uma divisão do ser humano. Para Tomás, o homem é um sínolo, ou seja indissociavelmente corpo e alma, onde o espírito estaria incutido na alma racional.
}

manter a estrutura-ção anímica feita por Aristóteles, ressignificando-a.

$\mathrm{Na}$ concepção aristotélico-tomista, a alma se "subdividiria" em três partes: alma vegetativa; alma sensitiva e alma racional. Comentemos sobre cada uma.

A alma vegetativa é o princípio elementar em todo os seres vivos, princípio que governa e regula as atividades biológicas. Exerce-se no órgão corpóreo e junto a ela estão presentes as potências vegetativas: nutritiva (alimentar), aumentativa (crescer), geratriz (reproduzir).

A concepção de alma sensitiva - que nos será particularmente útil neste trabalho - parte da idéia de que os seres vivos possuem funções que vão além das potências vegetativas, como sensações, apetites e movimento. Então se torna necessário um outro princípio que regeria tais funções, o qual corresponderia à alma sensitiva, "com efeito, na assimilação que se dá na nutrição é assimilada também a matéria, ao passo que na sensação é assinalada apenas a forma" (Reale \& Antiseri, 1990, p. 200).

Junto a esta parte da alma, estão as potências sensitivas, as quais se dividem em externas e internas. Tem-se nas externas uma relação imediata com a alma vegetativa, pois estas são em cinco - visão, audição, olfação, gustação e tato - e se relacionam diretamente com os respectivos órgãos corpóreos dos sentidos, onde "quando um sentido capta um sensível próprio, então a respectiva sensação é infalível" (Reale \& Antiseri, 1990, p. 200). Já as potências internas seriam em quatro: senso comum, imaginação, cogitativa e memorativa. Tomás as descreve em sua Suma:

Assim portanto, à recepção das formas sensíveis é destinado o sentido próprio e comum, de cuja distinção a seguir se tratará. - Porém, à retenção e à conservação dessas formas é destinada a fantasia ou imaginação que é um como tesouro das formas recebidas pelo sentido. - Ao passo que, a apreender as espécies intencionais, que não são recebidas pelo sentido, se destina a virtude estimativa. - E, por fim, a conservá-las se destina a virtude memorativa, que é o como tesouro de tais espécies intencionais. 
Pois, os animais percebem tais espécies só por um como instinto natural; ao passo que o homem, por uma certa comparação. E por isso, a chamada estimativa natural, nos animais, chama-se cogitativa no homem, que chega a tais espécies intencionais por uma certa comparação. Donde vem o chamar-se também razão particular, a qual os médicos assinalam um órgão determinado, a saber, a parte média da cabeça. Pois, é apreensiva das espécies intencionais individuais, assim como a razão intelectiva o é das espécies intencionais universais. $-\mathrm{E}$, quanto à memorativa, o homem não somente tem a memória, como os outros animais, pela recordação súbita das cousas pretéritas; mas também a reminiscência, pela qual indaga silogisticamente a memória do passado, segundo as espécies intencionais individuais (Aquino, 1934, p. 190).

Esse universo do sensível de orientação aristotélico-tomista é retomado posteriormente e redefinido, pela Segunda Escolástica (Falcon, 1997) ${ }^{7}$, através do Cursus Conimbricensis, elaborando de uma forma mais refinada a articulação entre as potências sensitivas, as quais produzem o conhecimento. Torna-se este o modelo interpretativo oficial da Companhia de Jesus. Zanlonghi (2003) traz a articulação de tal modelo, onde entre os quatro sentidos internos cabe a cogitativa um papel bastante particular.

\footnotetext{
${ }^{7}$ Segundo Falcon: "A partir de meados do século XVI, declina o Humanismo e fortalece-se a influência dos padres da Cia. de Jesus. Coube a estes desenvolver o que se convencionou chamar de "A Segunda Escolástica" Portuguesa, a qual foi exposta nos diversos textos da obra coletiva conhecida como Curso Conimbricense. Em sintese, seus autores conseguiram fundir, até onde isto foi possível, o Humanismo e a Escolástica. Do Humanismo os jesuitas utilizaram os métodos críticos e filológicos para restaurar a versão latina de Aristóteles e partilharam da sua rejeição à escolástica decadente, sobretudo a dos nominalistas e dos naturalistas italianos do século XV. A Escolástica jesuitica apóia-se principalmente em $S$. Tomás e outros autores do século XIII, porém a ótica cultural em que eles se situam é a do Humanismo, inclusive quanto ao desprezo ou a pouca importância que deram à filosofia da ciência. Em suma, com a Segunda Escolástica Portuguesa, tem-se, a partir da segunda metade do século XVI, uma Escolástica integrada no ambiente do Humanismo, mas também um Humanismo integrado na Escolástica".
}

Enquanto o senso comum produz a primeira unificação das informações sensíveis, a fantasia, mesmo movendose ainda no âmbito das res sensatas, inicia o processo de unificação na dispersão espaço temporal; todavia é somente com a cogitativa que se constitui um quasi thesaurus specierum, capaz de conjugar, conectar, e dignoscere res non sensatas.

Desta maneira, com a cogitativa o conjunto das informações sensíveis recebe uma nova e mais estável síntese; a cogitativa constitui-se como o ápice da organização da atividade sensitivo-imaginativa. Além do mais, essa é, segundo a lição de Tomas, ratio particularis, ou seja, mesmo pertencendo ao âmbito pré-racional, já se apresenta orientada ao universal. Colocada no limite com o intelecto, a cogitativa colhe, sem ainda conhecê-lo enquanto tal, o universal.

Zanlonghi (2003) também indica conseqüências desta maneira de estruturar o universo anímico. Antes de qualquer coisa, fica eliminado o equívoco acerca da passividade dos sentidos: esses, mesmo não operando discursivamente, concorrem ativamente para a intelecção. O intelecto agente age nos fantasmas, dá uma iluminação que o embebe de si. O estatuto quase universale do fantástico não se torna contraditório justamente quando não se interpreta dualisticamente a relação sensibilidade/intelecto, e pressupõe, ao contrário, um patrimônio imaginativo não fechado no âmbito do sensível, na medida em que já é tocado pela luz do inteligível. Sensibilidade e intelecto interagem até o ponto em que a virtus cogitativa apresenta uma estreita afinidade com o espírito; assiste-se a uma espiritualizarão da sensibilidade.

Tem-se, por final, a alma racional - para os gregos o que definia o homem, pois "o órgão dos sentidos não existe sem o corpo, enquanto a inteligência existe por sua própria conta" (Aristóteles conforme citado por Reale \& Antiseri, 1990, p. 200) - onde estaria situada a capacidade do inteligir, a vontade, a capacidade de elaborar um juízo acerca da realidade, e de apreender a intencionalidade das formas universais. Tomás toma o Intelecto como "uma potência da alma e não a essência mesma dela" (Aquino, 1934, p. 198). Assim a alma racional não se aparta das outras esferas anímicas: por exemplo, não pode prescindir do sensível, pois "o pensa- 
mento humano é ligado à sensibilidade; o intelligere compreende a sensibilidade, não pode prescindir dela: como Tomás havia já dito, conhecer é ter uma visão nos dados sensíveis" (Zanlonghi, 2003, p. 68).

Vieira, perpassando por toda essa construção do universo interior do homem e sua topografia, coloca na pregação, em seu "modo sacramental", o pregador como aquele que, em sua fala, reflete a realidade para o outro, mostrando sua real dimensão e significado enquanto sinal efetivo de Deus. Ou seja, a pregação tem como função o desengano, "pregação que descobre e ordena o futuro, ato de discurso que levanta os arranjos providenciais dispondo as coisas do mundo, arte a fazer saltar em frases de impacto as supra-razões que se acumulam na semrazão do que ocorre" (Pécora, 1994, p. 267). Para desenganar, o pregador "concorre com o espelho" da doutrina, porém é imprescindível a adesão do sujeito, de forma livre, à conversão:

Para uma alma se converter por meio de um sermão há-de haver três concursos: há-de concorrer o pregador com a doutrina, persuadindo; há-de concorrer o ouvinte com o entendimento, percebendo; há-de concorrer Deus com a graça, alumiando. (...) Que cousa é a conversão de uma alma senão entrar um homem dentro em si, e ver-se a si mesmo? Para esta vista são necessários olhos, é necessária luz, e é necessário espelho. O pregador concorre como e espelho, que é a doutrina; Deus concorre com a luz, que é a graça; o homem concorre com os olhos, que é o conhecimento (Vieira, 1993, p. 78).

Persuadir é desenganar. Na dinâmica da vida interior, a raiz "psicológica" da persuasão presente na retórica, consiste em mobilizar os sentidos internos através da vontade - a qual deve seguir a razão -, pelo uso da palavra com toda a sua força figurativa, procura mostrar as razões do Bem de um objeto, suscita o interesse da imaginação, ao agradar interpela o apetite solicitando o aceite.

\footnotetext{
${ }^{8}$ Sermão da Sexagésima.
}

O engano do mundo se daria também na esfera do sentidos internos, conforme descrito pelo próprio Vieira:

Dentro da nossa fantasia, ou potência imaginativa, que reside no cérebro, estão guardadas, como em tesouro secreto, as imagens de todas as coisas que nos entraram pelos sentidos, a que os filósofos chamam espécies. E assim como nós das letras $\mathrm{ABC}$, que são somente vinte e duas, trocando-as e ajuntando-as variamente, escrevemos e damos a entender o que queremos, assim o demônio, daquelas espécies, que são infinitas, ordenando-as como mais lhe serve, pinta e representa interiormente à nossa imaginação o que mais pode inclinar, afeiçoar e atrair $\mathrm{o}$ apetite. E deste modo mudamente nos tenta, mudamente nos persuade, e mudamente nos engana (Vieira, 1993, p. 1163)

Assim, o engano do demônio mudo agiria, tirando a real imagem das coisas do mundo e colocando em seu lugar a ilusão que fomenta os apetites, onde a vontade sucumbe ao desejo. Essa organização própria dos sentidos internos, que persuade silenciosamente enganando, é combatida com a palavra laboriosa, restituindo-se à vontade a regência política dos afetos:

Engana-nos o mal com a aparência de bem, e leva-nos o amor: engana-nos o bem com a aparência de mal, e mete-nos no coração o ódio. E que fará a triste vontade enganada assim e cativa? O desengano destes dous erros é o que eu determino pregar hoje; e ensinar, não as más, senão as boas vontades, como hão de saber amar, e como hão de saber aborrecer. É matéria em que depois de disputada a controvérsia, vos hei-de descobrir um admirável segredo (Vieira, 1993, p. 690) $)^{10}$.

Vieira parece retomar sua formação escolástica: segundo os Conimbricences, a vontade pressupõe o conhecimento, mas também depende do apetite sensitivo o qual, por sua vez, segue a fantasia:

\footnotetext{
${ }^{9}$ Sermão do Demônio Mudo.

${ }^{10}$ Sermão da Primeira Sexta-Feira da Quaresma.
} 
"voluntas rationis ductum sequitur, appetitus sensitivus immaginationem sive phantasiam". De modo que, em virtude da unidade alma-corpo, a esfera pré-racional dos apetites e das paixões interfere profundamente, seja no conhecimento, seja no livre arbítrio. A vontade, por sua vez, pode também agir sobre os apetites, para orientá-los e discipliná-los, tratando-os como cives da alma e não tanto como servos, sendo submetidos politicamente e não de maneira despótica. Os caminhos para realizar um governo político passam através dos sentidos internos, os quais são o lugar interior que permite a passagem para o intelecto e vontade. Neste processo, o papel da potência cogitativa é fundamental, sendo que a persuasão passa assim por ela. Cipriano Soares SI, no compêndio de retórica (Soares, 1580) indica o processo que une a vontade, a razão, a potência cogitativa e os apetites, evidenciando assim as raízes psicológicas da persuasão e da retórica: atuando sobre os sentidos interno, a palavra eloqüente suscita o interesse da imaginação. Ao tornar bela a própria verdade, através do aprazível, estimula o apetite e solicita a adesão. Portanto, move politice regendo, non cogendo. Assim, a retórica através do governo das paixões, estimula a adesão aos preceitos propostos.

No famoso Sermão da Sexagésima, o qual o próprio Vieira escolhe como prólogo à sua obra sermonária - "Servirá de prólogo aos sermões que vos hei-de pregar, e aos mais que ouvirdes esta Quaresma" (Vieira, 1993, p. 76) ${ }^{11}$ - , o pregador discute, dentre muitas outras coisas, sua arte retórica, o modo pelo qual deve o pregador ordenar seu discurso:

Há-de tomar o pregador uma só matéria, há-de defini-la para que se conheça, há-de dividi-la para que se distinga, há-de prová-la com a Escritura, há-de declará-la com a razão, há-de confirma-la com o exemplo, há-de amplifica-la com as causa, com os efeitos, com as circunstâncias, com as conveniências que se hão-de seguir, com os inconvenientes que se devem evitar, há-de de responder as dúvidas, há-de satisfazer às dificuldades, há-de impugnar e refutar com toda a força da eloqüência os argumentos contrários, e depois disto há-de

\footnotetext{
${ }^{11}$ Sermão da Sexagésima.

${ }^{12}$ Sermão da Sexagésima.
}

colher, há-de apertar, há-de concluir, há-de persuadir, há-de acabar. Isto é sermão, isto é pregar, e o que não é isto, é falar de mais alto. Não nego nem quero dizer que o sermão não haja de ter variedade de discurso, mas esse hãode nascer todos da mesma matéria, e continuar e acabar nela. Quereis ver tudo isto com os olhos? (Vieira, 1993, p. 90) ${ }^{12}$.

"Quereis ver tudo isto com os olhos?" Propõe Vieira. E o que ele traz na seqüência é uma imagem metafórica, criada com palavras, comparando o sermão a uma árvore com suas raízes, troncos, ramos, folhas, varas, flores e frutos as quais se ligam a Evangelho, assunto e matéria, discursos, ornamento de palavras, repreensões aos vícios, às sentenças e ao "fim que se há de ordenar o sermão" respectivamente (Vieira, 1993, p. 91) ${ }^{13}$. E assim, Vieira dá vida "diante dos olhos" à sua estrutura formal retórica, ou seja, é possível "ver pelos ouvidos" criando imagens metafóricas as quais presentificam conceitos e objetos. Criar imagens torna a coisa presente: ver é crer. Vieira propõe através do uso de metáforas toda uma construção imagética, requisitando fantasmas depositados na memória. $\mathrm{O}$ poder da imaginação na persuasão é amplamente difundido pelos jesuítas, estes o experienciam em sua formação nos exercícios espirituais propostos por Inácio de Loyola ${ }^{14}$ (1985).

No século XVII, uma conceituação muito precisa do significado e do uso das metáforas encontra-se na obra do jesuíta Tesauro (1965). Para este pensador, a metáfora pode ser definida como uma espécie de "óculo" aristotélico, conforme

\footnotetext{
${ }^{13}$ Sermão da Sexagésima.

${ }^{14}$ Inácio de Loyola nos Exercícios espirituais recomenda o uso sistemático da contemplação interior, utilizando os cinco sentidos da imaginação, de modo que o objeto da contemplação envolva o eu num espaço de imaginação mais certo e evidente do que o espaço real. Tais sentidos interiores substituem assim à realidade sensível, uma realidade de imaginação e de fé. Tratase do recurso inaciano da "compositio loci", uma complexa operação psíquica proposta na Segunda semana dos Exercícios Espirituais, através da qual o sujeito é conduzido a formar no seu interior através dos sentidos internos, a representação de um "lugar" onde é possível o envolvimento em primeira pessoa e que se tornará a seguir espaço de oração e de contemplação.
} 
expressão utilizada por Aristóteles (1934) na Rethorica, cuja função é a de pôr os objetos debaixo dos olhos para bem observá-los. Ela torna a linguagem aguda, de modo análogo ao efeito que a luneta produz na pupila. A metáfora penetra e investiga as noções mais abstrusas para acoplá-las de modo genial, tendo como resultado uma dilatação do campo semântico ordinário. Os vocábulos metafóricos carregam-se por uma multidão de imagens e noções, proporcionando ao olhar interior um espetáculo surpreendente: "parecendo à mente de quem ouve, ver num só vocábulo, um teatro pleno de maravilhas" (conforme expressão de Tesauro, citado em Jori, 1998, p. 156). A regra aristotélica da mesótes ou seja da medida e da temperança, é rejeitada pelos autores do século XVII, em favor da afirmação da audácia do engenho humano que, ao criar metáforas, identifica um conceito com outro aparentemente inconciliável. $\mathrm{O}$ engenho - faculdade intermédia entre razão e fantasia - torna-se então através da metáfora, capaz de expressar uma sorte de percepção sensorial do pensamento.

Porém, apesar do engenho do pregador, todo esse universo metafórico já dispõe de lugares argumentativos já pré-definidos, construídos pela visão de mundo dos homens da época. Assim, quando Vieira lança mão das possibilidades de sentido da metáfora, estes já possuem seu escopo próprio, como assinala Pécora:

Assim, pra encerrar, diria que o sermão tem seu início antes ainda de o padre Vieira compor uma só linha dele. Quando começa a pregação já uma maquinal de composição está em andamento, pronta a fornecer-lhe os principais análogos da invenção e metáforas da elocução, bem como os cruzamentos entre eles (Pecora, 2003, p. 91).

Além da parte formal da retórica, é possível estabelecer alguns recortes no texto, nos quais podese identificar como se dá o processo de persuasão, agindo este nos mecanismos internos da alma. Tais mecanismos, como já vimos, são bem estabelecidos e determinados pela filosofia da Segunda Escolástica. Nesta concepção a intelecção se dá tanto pela apreensão de espécies sensíveis, como espécies inteligíveis (impressas e expressas).
Neste dinamismo psíquico, a transformação da coisa para a palavra acontece segundo certa ordem: o objeto suscita, na inteligência do sujeito humano, a espécie sensível impressa, a qual origina a espécie sensível expressa, ou seja, a imagem, ou fantasma da coisa. Tal reprodução representativa do objeto, por sua vez, cria a espécie inteligível impressa, ou seja, proporciona a assimilação intelectual do objeto pela ação do intelecto agente, a saber, o seu reconhecimento pelo intelecto. Finalmente, este reconhecimento produz a espécie inteligível expressa, ou seja, à formulação do conceito, verbum mentis: a palavra. Em suma, o verbum mentis humano necessita sempre de um veículo sensível: a imagem. Portanto, a retórica enfatiza a função de sinal que a imagem tem, utilizando-se de processos analógicos e imaginativo.

Pode-se analisar tal dinâmica interna no seguinte trecho do Sermão da Sexagésima:

Quando Cristo mandou pregar os Apóstolos pelo mundo, disse-lhes desta maneira: (...) Ide, e pregai a toda criatura. Como assim, Senhor? Os animais não são criaturas? As árvores não são criatura? As pedras não são criaturas? Pois hão os Apóstolos de pregar às pedras? Hão-de pregar aos troncos? Hão-de pregar aos animais? Sim: diz S. Gregório, depois de Santo Agostinho. Porque como os Apóstolos iam pregar a todas as nações do mundo, muitas delas bárbaras e incultas, haviam de achar os homens degenerados em todas as espécies de criaturas: haviam de achar homens homens, haviam de achar homens brutos, haviam de achar homens troncos, haviam de achar homens pedras (Vieira, 1993, p. 73-74) . $^{15}$.

Vieira parte do gênero das criaturas (criaturas racionais, sensitivas, vegetativas e insensíveis) e chega ao temperamento dos homens. Como ele o faz? O discurso começa criando imagens, as quais partem de elementos básicos (elementares) - gênero das criaturas - recapitulando da memória conceitos correspondentes a percepções concretas (homem, animal, planta, pedra). A seguir, age na potência cogitativa, reelaborando conceitos: aproximando imagens passo a passo - imagens criadas por palavras

\footnotetext{
${ }^{15}$ Sermão da Sexagésima
} 
que trazem carga afetiva. $\mathrm{O}$ homem degenerado (em) passa a ser criatura (perde a origem, o ser). Homem degenerado em não "é", mas é "como se fosse", ou seja, o homem degenerado em pedra, não se torna pedra, mas é "como se fosse" (forma intencional) pedra. Aqui se substitui a idéia concreta de pedra (criatura/objeto), pela representação simbólica/afetiva que ela nos traz (intencionalidade) - é a forma intencional presente na fantasia sendo apreendida e ordenadamente na cogitativa. Através da intencionalidade captada, é possível passar do plano concreto do sensível (dureza, solidez, impenetrabilidade), para o universal abstrato (insensibilidade). Insensibilidade é categoria que qualifica uma posição ética, que apesar de remeter a "temperamento", "personalidade" e, portanto, requerer todo um processo de intelecção para definir o conceito, é acessível de forma bem mais direta, por ser intencional, se temos que é como pedra. $\mathrm{O}$ ouvinte pode não conseguir inteligir de forma "pura", racionalizando, mas pode entender a intenção que o discurso propõe, e é por isso que o inteligir passa através da sensibilidade. O Homem-Pedra reelaborado na cogitativa e devolvido à memória, remete então ao tópico de "vontade endurecida".

Oh! Deus nos livre de vontades endurecidas, que ainda são piores que as pedras. A vara de Moisés abrandou as pedras, e não pode abrandar uma vontade endurecida: Percutiens virga vis silicem, et eressae sunt aquale largissimae. Inratum est cor Pharaonis (Vieira, 1993 , p. 80) ${ }^{16}$.

Vieira coloca como exemplo (Aristóteles, 1994) ${ }^{17}$ para recapitular a idéia do Homem-Pedra, a figura bíblica do Faraó e sua vontade endurecida ${ }^{18}$. Retoma o último conteúdo da memória (Homem-

\footnotetext{
${ }^{16}$ Sermão da Sexagésima.

${ }^{17} \mathrm{O}$ exemplo trata-se de um artifício retórico que por meio indutivo estabelece uma verossimilhança: "Pues, en efecto: por una parte, el ejemplo es uma inducción; por outra parte, en fin, el entimema aparente es um silogismo aparente. Llamo, pues, entimema al silogismo retórico y ejemplo a la inducion retórica. $\mathrm{Y}$, ciertamente, en orden a demonstra, todos proporcionan pruebas por persuasión aduciendo ejemplos e entimemas, (de modo que) fuera de éstos no hay ninguma outra" .
}

Pedra), dá o exemplo bíblico (concreto) e por indução (Granada, 1945) ${ }^{19}$ o aplica a todo um gênero (tipo) de ouvinte - mobilizando novamente a potência cogitativa e estabelecendo uma "nova" memória: persuade.

Outro trecho que aponta modalidades de mobilização do dinamismo psíquico, no entanto, propondo uma reordenação de imagens e não uma aproximação delas, é este:

A definição do pregador é a vida e o exemplo. Por isso Cristo no Evangelho não o comparou ao semeador, senão ao que semeia. Reparai. Não diz Cristo: Saiu a semear o semeador, senão, saiu a semear o que semeia: Ecce exiit qui seminat, seminare. Entre o semeador e o que semeia há muita diferença: uma cousa é o soldado, e outra cousa o que peleja; uma cousa é o governador outra o que governa. Da mesma maneira, uma cousa é o semeado, e outra o que semeia; uma cousa é o pregador, e outra o que prega. O semeador e o pregador é nome; o que semeia e o que prega é acção; e as acções são o que dão o ser ao pregador. Ter nome de pregador, ou ser pregador de nome não importa nada; as acções, a vida, o exemplo, as obras, são as que convertem o mundo (Vieira, 1993, p. $82)^{20}$.

Ao falar do pregador, de sua pessoa (Vieira, 1993) ${ }^{21}$, novamente há uma reorganização na cogitativa, porém, ainda ao fazer associações, pretende-se dissociar elementos. Por exemplo, diferencia-se os termos: semeador-semear; soldadopelejar; governador-governar; pregador-pregar. Desta maneira, o foco não está mais no nome (palavra) que remete a conceitos, mas parte de um ação para definir o conceito. É o ato de semear que diz o que é o semeador e não a idéia do semeador. Obviamente a

\footnotetext{
18 Núm., XX, 11.

19 "Toda argumentacion, ó debe tratarse por induccion o por raciocinacion. Induccion es una oracion que por medio de cosas no dudosas logra el asenso de aquel a quiense dirige, com cuyos asensos hace que él conceda alguna cosa dudosa, en fuerza de la semejanza de aquellas, á que antes asintió."

${ }^{20}$ Sermão da Sexagésima.

${ }^{21}$ A pessoa é umas das circunstâncias que Vieira aponta para a caracterização do pregador.
} 
idéia do semeador é a do que semeia, mas Vieira parece querer causar um certo "estranhamento" quebrando o óbvio ao partir da ação - para valorizála - e não do termo (nome). Assim, o nome sem a ação ficaria vazio, assim como a pregação (nome) sem o exemplo (ação) fica vazio ${ }^{22}$.

\section{Conclusão}

Todo esse arcabouço de conhecimentos e a concepção de homem, representados aqui por meio da obra de Vieira, estiveram presentes no Brasil do século XVII, sendo um elemento de constituição da visão de mundo desse passado histórico. Através do estudo do tema da persuasão, pode-se constatar a idéia de dinamismo psíquico, enquanto idéia psicológica, como uma chave de leitura para compreender de que forma, na época, se estruturavam os conhecimentos sobre a vida interior do homem e seu congraçamento com a realidade do mundo material.

A esfera do psiquismo contingente ao homem é elaborada dentro da concepção de homem integrado, total, tanto em seu campo interior, seus afetos, paixões, vontade, intelecto, espírito, que se articulam entre si, como ser integrado ao mundo. Este Homem só se atualiza e tem sentido de ser, porque está imerso em uma realidade concreta, num mundo sensível; este último é ligado diretamente a um mundo transcendente, através da "sacramentalidade", ou seja, da possibilidade de todas as coisas e fatos serem sinais e presentificação de um sentido maior e mais amplo de certa transcendência, aqui ligado a uma universalidade, e, por conseguinte, à divindade. Fazendo uma analogia entre a alma aristotélicotomista e o ser do homem do século XVII, sendo a primeira una e indissociável, ao mesmo tempo em que se apresenta em suas três instâncias (vegetativa, sensitiva e racional), também o homem constitui-se de sua materialidade, de sua psique e de seu aspecto transcendente, os quais se articulam entre si, ao passo que simultaneamente são a imagem de um todo.

\footnotetext{
${ }^{22}$ Aqui parece haver uma crítica ao nominalismo, filosofia muito presente na época e combatida a partir do Concílio Tridentino.
}

E é este o motivo da pregação possuir toda essa sua força e reunir tantos fatores e conceitos em torno de si, justificando assim o destaque que tem no período: é a palavra laboriosa que perpassa toda a estrutura do homem - psique, materialidade e transcendência - e a articula de forma conjunta e unitária, integrando-a. Por isso a palavra persuade: promove uma identificação entre pregador, o outro e o mundo, numa dinâmica passional, onde é exigido do pregador um conhecimento de si mesmo, para então entrar em "diálogo" com a afetividade alheia, se identificando e se fazendo identificar. A palavra ao desenganar, restitui o valor ético da ação humana - a morada própria do homem, um modus vivendi -, promovendo a integração da estrutura humana, o homem total.

\section{Referências}

Aquino, T. (1934). Suma teológica. Parte IQuestões 75-83 (A. Correia, trad.). São Paulo: Gráfica Siqueira. (Original latino do Século XII).

Aristóteles. (1994). Retórica. Madrid: Editorial Gredos. (Original grego do Século IV a.c.).

Assis, R. M. (2004). Psicologia, educação e reforma dos costumes: Lições da Selecta Catholica (1846-1847). Tese de doutorado não publicada, Universidade Federal de Minas Gerais, Belo Horizonte.

Bergamo, M. (1991). L'Anatomia dell'Anim: Da François de Sales a Fénelon. Bologna: Il Mulino.

Falcon, F. J. C. (1997). A cultura renascentista portuguesa [versão eletrônica]. Semear, (1). Retirado em 16 novembro 2004, de http://www.letras.pucrio.br/catedra/revista/1Sem 03. html

Granada, L. (1945). Seis libros de la retorica eclesiastica de la manera de predicar (Tomo 3). Madrid: BAE.

Jori, G. Per evidenza. Conoscenza e segni nell'età barocca. Torino, Marsílio, 1998.

Loyola, I., Exercícios Espirituais, São Paulo, Edições Loyola, 1985.

Maraval, J. A. (1997). A cultura do barroco. São Paulo, SP: EDUSP. 
Massimi, Marina (2000). A história das idéias psicológicas: uma viagem no tempo rumo aos novos mundos. Em: Zélia Maria Mendes BiasoliAlves \& Geraldo Romanelli. Diálogos Metodológicos sobre prática de pesquisa. Ribeirão Preto: FFCLRP.

Pécora, A. (1994). Teatro do sacramento. São Paulo, SP: Edusp/Unicamp.

Pécora, A. (2003). Para ler Vieira: As 3 pontas das analogias nos sermões. Revista Portuguesa de Filologia, 25, 83-91.

Reale, G., \& Antiseri, D. (1990). História da filosofia: Antiguidade e Idade Média (Vol. 1). São Paulo, SP: Paulinas.

Soares, C., (1580) De arte retórica. Ex Aristotele, Cicerone et Quintiliano precipue deprompt, nunc ab eodem recogniti et multis in locis locupletis. Roma, F. Zanettum. Libri III.

Tesauro, E. (1965). Il cannocchiale aristotelico. In E. Raimond, Trattatisti e narratori del seicento (La letteratura italiana, Vol. 36, pp. 19-106). Milano: Ricciardi.

Vieira, A. (1993). Sermões (Obras completas do Padre Antônio Vieira, Vol. 1). Porto: Artes Gráficas.

Zanlonghi, G. (2003). La psicologia e il teatro nella riflessione gesuitica europea del cinqueseicento [versão eletrônica]. Memorandum, 4, 61-85. Retirado em 25 agosto 2004, de http: \|www.fafich.ufmg.br/ memorandum/ artigos04/zanlonghi01.htm

Este artigo foi escrito a partir de pesquisa financiada por bolsa de iniciação científica do Conselho Nacional de Desenvolvimento Científico e Tecnológico (CNPq).

Artigo recebido em 03/10/2005.

Aceito para publicação em 09/04/2007.
Endereço para correspondência:

Sandro Rodrigues Gontijo. Av. João Machado Borges, 106. CEP: 38040-350. Uberaba-MG, Brasil. E-mail: sandrogontijo@yahoo.com.br

Sandro Rodrigues Gontijo é psicólogo; mestrando junto ao Departamento de Pós-graduação da Faculdade de Filosofia Ciências e Letras de Ribeirão Preto da Universidade de São Paulo.

Marina Massimi é Livre Docente junto ao Departamento de Psicologia e Educação na Faculdade de Filosofia Ciências e Letras de Ribeirão Preto da Universidade de São Paulo. Especialista na área de História das Idéias Psicológicas na Cultura Luso-Brasileira. 